\title{
Efficacy of Normal Maize versus Quality Protein Maize on the Performances of Growing Yaks
}

\author{
D. Medhi ${ }^{1 *}$, V. Paul ${ }^{1}$, T. P. Singh ${ }^{1}$, M. Hussain ${ }^{1}$, S. L. Jat ${ }^{2}$, \\ P. Chakravarty ${ }^{1}$, M. Sarkar ${ }^{1}$ and S. Rakshit ${ }^{3}$
}

${ }^{1}$ Indian Council of Agricultural Research-National Research Centre on Yak, Dirang, West Kameng District, Arunachal Pradesh, Pin-790101, India

${ }^{2}$ ICAR-Indian Institute of Maize Research, Pusa, New Delhi-110012, Delhi, India

${ }^{3}$ ICAR-Indian Institute of Maize Research, PAU Campus, Ludhiana-141 004, Punjab, India

*Corresponding author

\section{A B S T R A C T}

\section{Keywords}

Growth

performance, Yak, maize, Quality protein maize, digestibility, nitrogen balances

Article Info

\section{Accepted:}

15 June 2021

Available Online:

10 July 2021
Ten growing yaks of uniform age (6 to7 months) and body weights $(49.7 \pm 0.94 \mathrm{~kg})$ were randomly divided into two groups of five animals in each and were fed on mixed rations for a period of 112 days. The normal maize part of the concentrates in Ration-1 $\left(\mathrm{R}_{1}\right)$ was completely (w/w) replaced with QPM in Ration- $\mathrm{R}_{2}$ and offered to group $T_{1}$ and $T_{2}$, respectively. Standard managemental practices were adopted for all the experimental animals. At the end, a metabolism trial of 6 days duration was carried out in all yaks. The average DMI/100 kg body weight and average daily gain were higher with better feed efficiency in the group $\mathrm{T}_{2}$ fed diets based on quality protein maize. The nutritive values in terms of Digestible Crude Protein (DCP) and Total Digestible Nutrients (TDN) showed no significant variations between the groups and the values were 5.00 \pm 0.47 and $56.54 \pm 1.08$ and $5.25 \pm 0.24$ and $57.63 \pm 1.14$ percent in group $\mathrm{T}_{1}$ and $\mathrm{T}_{2}$, respectively. The digestibility as well as the nutrient balances increases with $5 \%$ reduction of feed cost of growing yaks in $\mathrm{T}_{2}$ fed quality protein maize based diets replacing normal maize in $\mathrm{T}_{1}$. It was concluded that normal maize can easily be replace with quality protein maize for growing yaks for higher economic returns.

\section{Introduction}

Maize is the second most important crop after rice in the North Eastern Himalayan region (NEHR) of India. In this region maize production plays an important role in the livelihood of farmers ensuring their food security and grown under foothills and hilly terrains of the state. People used maize both for direct consumption as well as for the second cycle production in livestock. It plays a potential role as a source of human food, 
animal and poultry feed and as industrial products. It is a primary source of energy supplement and can contribute up to 30 percent protein, 60 percent energy and 90 percent starch in an animal diet (Dado, 1999). It have been recorded, the local verities of maize are deficient in its protein content to some extends and its compositions in terms of essential amino acids namely lysine and tryptophan contents (Keretsu et al., 2019). To overcome this problem, the maize breeder had developed quality protein maize (QPM) which contains higher level of lysine and tryptophan with lower content of leucine for maintaining a balance ratio of leucine to isoleucine that's need for enhancement of the biological value of the protein. It is reported that supplementation of QPM improves the growth, feed efficiency and economics of feeding in different types of animals. Yak (Poephagus grunniens) inhabits in difficult terrains of the foot hills of Himalayas, plays a major role in the economy of the tribal population of Arunachal Pradesh. Yaks are taxed heavily in winter due to inadequate fodder resulting 25 to 30 per cent loss of body weight and the milk yields (Baruah et al., 2012) and needs supplementation of concentrates with balanced amino acid compositions especially during winter. Hence, the study was planned to assess the nutritional evaluation of quality protein maize in comparison to normal maize in yak calves.

\section{Materials and Methods}

The study was conducted at Nyukmadung yak farm under ICAR-NRC on Yak, Dirang, India situated at an altitude of $7500 \mathrm{ft}$. above msl. Ten numbers of growing male yak calves of uniform age (6 to 7 months) and body weights $(49.7 \pm 0.94 \mathrm{~kg}$ body weights) were randomly divided into two groups of five animals in each. The animals were fed individually with paddy straw as dry roughage with $0.5 \mathrm{~kg}$ of green Dactylus glomerata as roughage and concentrate mixture in the ratio of $2: 1$ for a period of 112 days. The ingredients of composition of the concentrate mixture was normal maize, wheat bran, ground nut cake, mustard oil cake, mineral mixture and common salt in the proportion of $50,20,15$, 12,2 and 1 percent, respectively in Ration$\mathrm{R}_{1}$ and the proportionate amount of the normal maize was quantitatively (w/w) replaced with QPM in Ration- $\mathrm{R}_{2}$ and the same was offered to the experimental animal group $T_{1}$ and $T_{2}$, respectively. All the experimental animals were fed individually under stall feeding for 112 days on mixed rations containing both concentrate mixtures and paddy straw. Green grasses (Dactylus glomerata) were offered to the all the experimental animals at the rate of $0.5 \mathrm{~kg} / \mathrm{animal} /$ day to meet out their Vitamin A requirements. At random one dietary treatment was allotted to each group. Standard managemental practices were applied for each animal. Fresh drinking water was made available at any time to the experimental animals during the whole experimental period. The fortnightly body weights and daily feed intake of the animals were recorded for calculation of average daily gain and dry matter intake of the experimental animals.

A metabolism trial was conducted on all experimental yaks at the end of 112 days of the experimental feeding for a period of six days and the samples of feed, faeces and residue left collected were analyzed for proximate composition according to AOAC (2007). Digestible energy (DE) was calculated as $1.0 \mathrm{~kg}$ Total Digestible Nutrient (TDN) being equal to $4.4 \mathrm{Mcal} \mathrm{DE}$ and metabolizable energy (ME) was equal to 0.821 times of $\mathrm{DE}$ as per Agnew and Yan (2000). Calcium and phosphorus were estimated by modified methods of Talapatra et al., 1940. The data were subjected to statistical analysis by paired " $t$ test" for every measurements using statistical package Minitab, 2003, version 13.20. 


\section{Results and Discussion}

The chemical compositions of paddy straw, Dactylus glomerata and experimental concentrate mixtures with normal maize $\left(\mathrm{R}_{1}\right)$ and QPM $\left(\mathrm{R}_{2}\right)$ in terms of their dry matter, organic matter, crude protein, crude fibre, ether extract, total ash, nitrogen free extract contents along with their fibre components were presented in Table 1 and it was observed all the findings of the present study were within the range of the reported values of Ghosh and Bandopadhyay, 2008, Baruah et al., 2012 and Medhi et al., 2018.

It also indicated, the compositions of concentrates changes with replacement of the normal maize by QPM although their values were with the reported range of earlier workers for yak feeds (Baruah et al., 2012 and Medhi et al., 2015).

The average daily gain in body weights of the experimental yak calves were slightly higher in group- $\mathrm{T}_{2}(0.270 \mathrm{~kg} \pm 0.01)$ against the group- $\mathrm{T}_{1}(0.277 \mathrm{~kg} \pm 0.05)$, though the values showed no significant variations between the groups (Table 2). The higher level of protein with better amino acid compositions probably higher content of lysine and tryptophan in QPM might be the reason for better growth in $\mathrm{T}_{2}$. Similar observations of better growth in yak calves with increased protein level in yak rations were also observed by Medhi et al., 2018. The findings of the present study were in congruence with the findings of Keretsu $e t$ al., 2019, who recorded significant increased in growth rate of growing mithun calves with replacement of normal maize with QPM.

Ladely et al., 1995 also recorded similar findings and reported that ruminants attributed nutritional benefits in terms of weight gain with high lysine corn. During 112 days of experimental feeding, the daily dry matter intake $(1.70 \mathrm{~kg} \pm 0.12$ and $1.69 \mathrm{~kg} \pm 0.26)$ and the per cent average dry matter intake (DMI/100 $\mathrm{kg}$ body weight) were $1.95 \pm 0.09$ and $1.90 \pm 0.12 \mathrm{~kg}$ in $\mathrm{T}_{1}$ and $\mathrm{T}_{2}$, respectively and the values showed no significant variations with replacement of normal maize by quality protein maize (Table 2). Likewise, there were no significant variations in feed efficiencies in yak calves between the groups though their feed intake per unit gain decreases with substitution of normal maize $\left(6.03 \pm 0.62\right.$ in $\left.\mathrm{T}_{1}\right)$ with quality protein maize $\left(6.31 \pm 0.44\right.$ in $\left.\mathrm{T}_{2}\right)$. The findings were well matched with the reports of Beek and Dado, 1998 and Keretsu et al., 2019 who also recorded no significant variations in feed intake and its efficiencies with QPM based concentrate feed with higher lysine contents in ruminants.

The digestibility co-efficient of dry matter as well as different organic nutrients represented in Table 3 and the values for crude protein and nitrogen free extracts digestibility were significantly $(\mathrm{P}<0.05)$ higher in $\mathrm{T}_{2}$ group than $\mathrm{T}_{1}$ and the results were well matched with the findings of Andrew et al., 1979 and Keretsu et al., 2019. The reason might be due to higher lysine and tryptophan content of quality protein maize in comparison to normal maize Tiwari et al., 2013 also revealed higher digestibility of different organic nutrients with QPM based diets in growing pigs. The better digestibility of the nutrients with higher lysine content in the diets influences the gut of the animals that's affects amino acid contents of excreta was also revealed by Short et al., 1999.

The nutritive values in terms of Digestible Crude Protein (DCP) and Total Digestible Nutrients (TDN) of the experimental rations with normal maize $\left(T_{1}\right)$ and its replacement with incorporation of quality protein maize $\left(\mathrm{T}_{2}\right)$ on dry matter basis were presented in Table 3 and the values recorded as $5.00 \pm 0.47$ and $56.54 \pm 1.08$ and $5.25 \pm 0.24$ and $57.63 \pm 1.14$ percent in group $T_{1}$ and $T_{2}$, respectively. 
Table.1 Proximate composition of different feed components and the experimental rations

\begin{tabular}{|c|c|c|c|c|c|c|}
\hline Parameters & $\begin{array}{c}\text { Normal } \\
\text { maize }\end{array}$ & $\begin{array}{c}\text { QPM } \\
\text { (Shaktiman) }\end{array}$ & Paddy straw & $\begin{array}{c}\text { Green } \\
\text { Fodder } \\
\text { (Dactylus } \\
\text { glomerata) }\end{array}$ & $\begin{array}{c}\text { Concentrate } \\
\text { mixture } \\
\text { with NM } \\
\left(\mathbf{R}_{\mathbf{1}}\right)\end{array}$ & $\begin{array}{c}\text { Concentrate } \\
\text { mixture with } \\
\text { QPM }\left(\mathbf{R}_{\mathbf{2}}\right)\end{array}$ \\
\hline Dry matter & $87.66 \pm 0.95$ & $89.65 \pm 0.89$ & $87.12 \pm 2.14$ & $27.8 \pm 1.24$ & $87.86 \pm 1.47$ & $88.02 \pm 1.22$ \\
\hline Organic Matter & $95.79 \pm 1.14$ & $97.42 \pm 1.27$ & $84.80 \pm 2.12$ & $90.2 \pm 3.14$ & $90.30 \pm 2.34$ & $90.88 \pm 2.05$ \\
\hline Crude Protein & $8.31 \pm 0.04$ & $9.86 \pm 0.08$ & $3.20 \pm 0.23$ & $13.4 \pm 1.04$ & $17.61 \pm 0.65$ & $18.18 \pm 0.43$ \\
\hline Crude Fibre & $2.36 \pm 0.02$ & $2.52 \pm 0.01$ & $32.00 \pm 0.34$ & $21.1 \pm 1.22$ & $7.10 \pm 0.42$ & $6.20 \pm 0.33$ \\
\hline Ether Extract & $3.06 \pm 0.03$ & $3.26 \pm 0.03$ & $1.00 \pm 0.08$ & $3.3 \pm 1.03$ & $4.38 \pm 0.23$ & $4.35 \pm 0.09$ \\
\hline Total ash & $2.21 \pm 0.01$ & $2.08 \pm 0.01$ & $15.20 \pm 0.12$ & $9.8 \pm 0.75$ & $9.70 \pm 0.41$ & $9.30 \pm 0.24$ \\
\hline $\begin{array}{c}\text { Nitrogen Free } \\
\text { Extract }\end{array}$ & $84.06 \pm 1.24$ & $82.28 \pm 1.24$ & $48.60 \pm 1.24$ & $52.4 \pm 2.11$ & $61.22 \pm 1.56$ & $59.87 \pm 1.07$ \\
\hline
\end{tabular}

Means within the same row bearing the same superscript do not differ significantly

Table.2 Effect of replacing normal maize with QPM on growth performances, feed efficiency and economics of feedings on growing yak calves (Mean $\pm \mathrm{SE}$ )

\begin{tabular}{|c|c|c|}
\hline Particulars & \multicolumn{1}{|c|}{$\mathbf{T}_{\mathbf{1}}$} & $\mathbf{T}_{\mathbf{2}}$ \\
\hline \multicolumn{1}{|c|}{ Performances of the yak calves } \\
\hline Initial body weight (Kg) & $56.8 \pm 3.61$ & $56.6 \pm 3.93$ \\
\hline Final body weight (Kg) & $87.0 \pm 3.72$ & $87.6 \pm 8.42$ \\
\hline Experimental period & \multicolumn{2}{|c|}{112 days } \\
\hline Total weight gain/loss at 112 days (Kg) & $30.200 \pm 0.96$ & $31.012 \pm 5.99$ \\
\hline Average daily gain (kg) & $0.270 \pm 0.01$ & $0.277 \pm 0.05$ \\
\hline Voluntary Intake (kg/day) & $1.93 \pm 0.14$ & $1.92 \pm 0.30$ \\
\hline DMI per day (kg) & $1.70 \pm 0.12$ & $1.69 \pm 0.26$ \\
\hline DM intake, kg/100kg body weight & $1.95 \pm 0.09$ & $1.90 \pm 0.12$ \\
\hline FCR (DMI, kg/kg gain in body weight) & $6.31 \pm 0.44$ & $6.03 \pm 0.62$ \\
\hline Economics of feeding \\
\hline Cost of feeding per kg gain (Rs.)
\end{tabular}

Means within the same row bearing the same superscript do not differ significantly 
Table.3 Effect of replacing normal maize with QPM on digestibility and plane of nutrition on growing yak calves (Mean $\pm \mathrm{SE}$ )

\begin{tabular}{|c|c|c|}
\hline Particulars & $\mathbf{T}_{1}$ & $\mathbf{T}_{2}$ \\
\hline \multicolumn{3}{|c|}{ Digestibility co-efficient (\%) } \\
\hline Dry matter & $61.23^{\mathrm{a}} \pm 0.72$ & $63.02^{\mathrm{b}} \pm 1.07$ \\
\hline Crude protein & $62.45^{\mathrm{a}} \pm 1.14$ & $64.11^{b} \pm 0.72$ \\
\hline Ether Extract & $64.22 \pm 0.24$ & $65.24 \pm 0.22$ \\
\hline Crude fibre & $61.12 \pm 0.86$ & $61.98 \pm 0.14$ \\
\hline Nitrogen free extract & $64.35^{\mathrm{a}} \pm 0.42$ & $66.41^{b} \pm 1.02$ \\
\hline \multicolumn{3}{|c|}{ N balances (g/day) } \\
\hline $\mathbf{N}$ intake & $94.24^{\mathrm{a}} \pm 1.65$ & $98.75^{b} \pm 1.13$ \\
\hline Faecal N voided & $19.46 \pm 0.57$ & $18.98 \pm 0.34$ \\
\hline Urinary $\mathbf{N}$ voided & $17.54 \pm 0.43$ & $16.63 \pm 0.62$ \\
\hline N balances & $57.24^{\mathrm{a}} \pm 0.74$ & $64.10^{b} \pm 1.12$ \\
\hline \multicolumn{3}{|l|}{ Nutritive values of ration (\% DM) } \\
\hline DCP $(\%)$ & $5.00 \pm 0.47$ & $5.25 \pm 0.24$ \\
\hline TDN (\%) & $56.54 \pm 1.08$ & $57.63 \pm 1.14$ \\
\hline Plane of Nutrition & & \\
\hline \multicolumn{3}{|c|}{ DCP intake } \\
\hline g/d & $85.00 \pm 1.21$ & $87.15 \pm 1.47$ \\
\hline $\mathrm{g} / 100 \mathrm{~kg} \mathrm{BW} / \mathrm{d}$ & $97.50 \pm 1.24$ & $99.75 \pm 2.01$ \\
\hline \multicolumn{3}{|c|}{ TDN intake } \\
\hline g/d & $961.18 \pm 7.84$ & $956.66 \pm 8.07$ \\
\hline $\mathrm{g} / 100 \mathrm{~kg} \mathrm{BW} / \mathrm{d}$ & $1102.53 \pm 11.24$ & $1094.97 \pm 12.4$ \\
\hline DE intake (Mcal/d) & $4.23 \pm 0.41$ & $4.21 \pm 0.24$ \\
\hline DE intake (Mcal/100kg BW/d) & $4.85 \pm 0.24$ & $4.82 \pm 0.17$ \\
\hline ME intake (Mcal/d) & $3.47 \pm 0.61$ & $3.46 \pm 0.09$ \\
\hline ME intake (Mcal/100kg BW/d) & $3.98 \pm 0.18$ & $3.96 \pm 0.12$ \\
\hline
\end{tabular}

Means within the same row bearing the same superscript do not differ significantly 
Fig.1 Performances of growing yak calves on normal maize versus QPM based diets

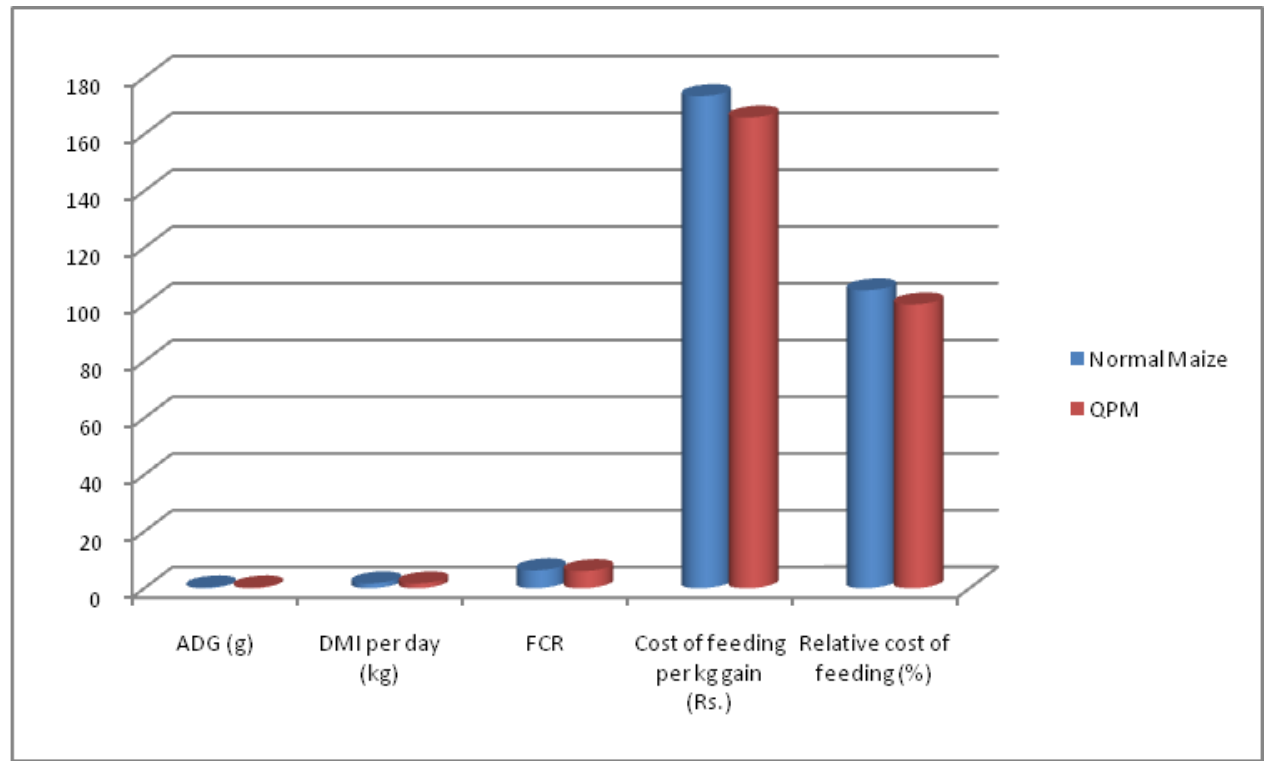

Fig.2 Plane of nutrition of the experimental yak calves on normal maize versus QPM based diets

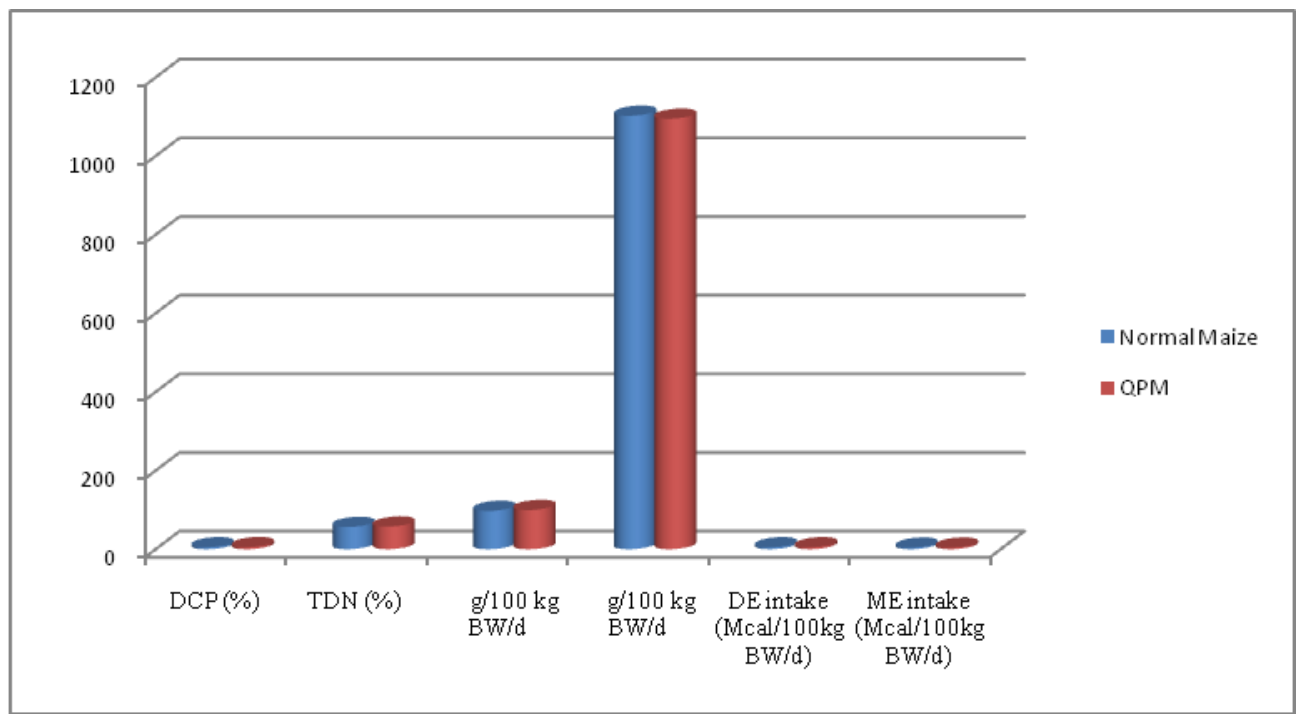

However, there were no significant variations between the groups for both DCP and TDN values.

The nitrogen balances as well as the energy values in term of Digestible Energy (DE) and Metabolizable Energy (ME) were significantly $(\mathrm{P}<0.05)$ higher in $\mathrm{T}_{2}$ than that of $\mathrm{T}_{1}$ group (Table 3). Higher digestibility of nutrients through substitution of normal maize with
QPM might be the reason for improved nitrogen and energy balances in $T_{2}$ group of yak calves in the study and the findings were in congruence with the findings of Dado (1999), Short et al., 1999 and Keretsu et al., 2019.

The cost of feeding calculated on the basis of feed cost per unit gain in body weights of the experimental calves fed diets containing 
quality protein maize replacing normal maize was Rs. 173.44 against Rs. 165.87 and it indicates $5 \%$ reduction of feed cost of growing yaks through incorporation of quality protein maize replacing normal maize in the diets of growing yak calves.

The present study revealed complete substitution of quality protein maize in the concentrate mixture have beneficial effects in term of growth rate, digestibility and nutrient balance, feed efficiency, plane of nutrition with superior economic returns in growing yaks without any adverse effect on their health status. It was concluded that normal maize can easily be replace with quality protein maize for growing yaks for higher economic returns.

\section{Acknowledgement}

The authors are thankful to the Director, Indian Council of Agricultural ResearchIndian Institute of Maize Research, Ludhiana for providing financial support under $\mathrm{NEH}$ grant of the institute and also grateful to the Director, Indian Council of Agricultural Research-National Research Centre on Yak, Dirang, Arunachal Pradesh for providing facilities for undertaking this study.

\section{Conflict of Interest}

All the authors declare no conflicts of interest for publishing the article in "International Journal of Current Microbiology and Applied Sciences"

\section{References}

Agrew, R. E. and Yan, T. 2000. Impact of recent reaserch on energy feeding systems for dairy cattle. Livestock Production Science, 66: 197-215

Andrew, S. M., Clark, J. H. and Davis, C. L. 1979. Feeding of opaque- corn grain and corn silage for lactating dairy cow,
Journal of Dairy Science, 62: 16191625

A.O.A.C. 2007. Official Methods of Analysis $\left(17^{\text {th }}\right.$ edn.) Association of Official Analytical Chemists, Arlington, Virginia, USA

Baruah, K. K., Paul, V., Ahmed, F. A., Chakravarty, P., Deori, S., Sarma, H., Saikia, A. 2012. Effect of strategic feed supplementation on growth performance and nutrient utilization in yak calves during winter. Indian Journal of Animal Sciences 82: 22022.

Beek, S. D., Dado, R. G. 1998. Nutritional value of high lysine corn or regular corn as grain or silage for lactating Holsteins, Journal of Dairy Science, 81: 1202

Dado, R. G. 1999. Nutritional benefits of specialty maize grain hybrids in dairy diets. Journal of Dairy Science, 82 (Suppl. 2): 197-207

Ghosh, M. K., Bandopadhyay, S. 2008. Effect of feeding regimes on growth performance and nutrient digestibility of Indian yaks under semi intensive system. Indian Journal of Animal Sciences 78(1): 117-119

Keretsu, V. J., Vidyarthi, V. K., Zuyie, R. 2019. Evaluation of quality protein maize in mithun calves (Bos Frontalis). Livestock Research International, 7(2): 68-70

Ladely, S. R., Stock, R. A., Klopfenstein, T. J., Sindt, M. H. 1995. High lysine corn as a source of protein and energy for finishing calves. Journal of Animal Science, 73: 228-235

Medhi, D., Santra, A., Paul, V., Saikia, A., Das, P. P., Ali, E., Deb, S. M. 2016. Performance of growing yak calves on different planes of nutrition, Indian Journal of Animal Sciences 86 (11): 1337-1339

Medhi, D., Santra, A., Paul, V., Deb, S. M. 
2018. Effect of plane of nutrition on blood biochemical parameters and attainment of sexual maturity in growing yaks, Indian Journal of Animal Sciences 88 (4): 81-84

Minitab, 2003. Minitab: Data Analysis, Statistical and Process improvement tools, version 13.20

Short, F. J., Wiseman, J., Boorman, K. N. 1999. Application of a method to determine ileal digestibility of amino acids in wheat in broiler. Animal Feed Science and Technology, 79: 195-209

Talapatra, S. K., Ray, S. C., Sen, K. C. 1940.
The analysis of mineral constituents in biological materials. i. Estimation of phosphorus, calcium, manganese, sodium and potassium in feed stuffs. Indian J. Vet. Sc. \& A. H. 10:243-56

Tiwari, M. R., Chapgain, P. B., Shah, M. K., Shrestha, Y. K. 2013. Evaluation of quality protein maize (QPM) and normal maize for growth performance of crossbred piglets in western hills of Nepal, Global Journal of Science Frontier Research (D), 13(6) version 1: $1-6$.

\section{How to cite this article:}

Medhi, D., V. Paul, T. P. Singh, M. Hussain, S. L. Jat, P. Chakravarty, M. Sarkar and Rakshit, S. 2021. Efficacy of Normal Maize Versus Quality Protein Maize on the Performances of Growing Yaks. Int.J.Curr.Microbiol.App.Sci. 10(07): 301-308.

doi: https://doi.org/10.20546/ijcmas.2021.1007.032 